\title{
Homologous Gene
}

National Cancer Institute

\section{Source}

National Cancer Institute. Homologous Gene. NCI Thesaurus. Code C28709.

A gene from one species which corresponds to a gene in another species and that is related via a common ancestral species. These genes retain a similar sequence and function. 